\title{
Applying Self-Directed Learning Method in Augmenting Student's Competence and Motivation in Entrepreneurship Class at English Department of Universitas Andalas
}

\author{
Dhiant Asri ${ }^{1,2, *}$ Shilva Lioni ${ }^{1}$
}

\author{
${ }^{1}$ Universitas Andalas \\ ${ }^{2}$ Universitas Andalas \\ *Corresponding author. Email: dhiantasri@hum.unand.ac.id
}

\begin{abstract}
The aim of this course is to augment student's mindsets, attitudes and personalities in order to be creative and innovative in entrepreneurship. Students were trained to plan, start and manage a new business. In this case, Self-Directed Learning (SDL) method was applied in the entrepreneurship course. This method was adjusted to Work from Home (WfH) and Study from Home (SfH) due to the Covid-19 pandemic. The SDL method was applied to foster the student's independence in learning and doing business. Therefore, the study of the application of SDL method in the entrepreneurship course was to analyze student's competence and motivation after doing SDL. Student collected the data individually from business people around them and also from YouTube. Then, student created a Simple Business Plan (SBP) and run the business personally. In controlling the student's business, peer review and class discussion were done in some meetings. Finally, the students returned to the class and presented their sales results and findings. In the finding of this research, student showed better competence and higher motivation in entrepreneurship.
\end{abstract}

Keywords: Self-Directed Learning (SDL) method, entrepreneurship course, and The Simple Business Plan $(S B P)$

\section{INTRODUCTION}

Entrepreneurship is a compulsory subject at the English Department of Universitas Andalas. This course has 2 credits and is allocated for 6th semester students in the even semester 2019/2020. The teaching and learning activities of entrepreneurship class is divided into classes A and B with two different lecturers. In this research, only Class A is analyzed. Learning Outcomes in the entrepreneurship course are reflected in the attitude, knowledge, General Skills and Special Skills that each student must have.

In English Department, the learning outcomes of entrepreneurship course are outlined in the Lesson Plan compiled on January 22, 2018. In this case, entrepreneurship course is expected to have a contribution to the competence of graduates later. There are 6 learning outcomes in entrepreneurship course. Students understand the meaning of entrepreneurship and are able to change their mindset to become entrepreneur, students are able to see any opportunities and build creative and innovative ideas; students know how to set up a business, form business organizations, and assess business needs; students know payment transactions, obtaining capital and applying loans; students are able to manage human resources, understand marketing strategies, and analyze competitors, and students are able to compile financial reports and analyze financial reports.

Like other courses, the entrepreneurship has the implementation on the development of the teaching and learning activities. The teaching materials of entrepreneurship include handouts and power point slides that have been distributed to students in order to understand the concept comprehensively. Lecturing method and group or class discussions have been applied in previous semester. Writing and presenting reports on the entrepreneurship have been used to assess and measure student's learning outcomes. The distribution of scores on the assignments, UTS (Mid Term Exam) and UAS (Final) were parameters of graduates in this course.

Kasali in the entrepreneurship module for the Undergraduate Program [1] explains that the purpose of giving entrepreneurship course is to elicit student's interest in starting become entrepreneur and making innovative business plan that will be different from other businesses. The trick is to learn immediately and become an entrepreneur of a business that students are familiar with and like. This presentation illustrates the importance of the entrepreneurship as a reference for undergraduate students to become an entrepreneur as early as possible. Students are expected to try various new innovations to build an independent business that is unique and accepted by the community. 
The application of Student-Cantered Learning (SCL) in the entrepreneurship course has the impact on the growing of student's interest to start their own business. It could be seen in the activeness of some student's participation in entrepreneur activities such as resellers, open booths, direct selling, offering computer services, make up, and photography, participations in entrepreneurship seminars and getting grants from the university. Some of the other students had business related to their background in English. They worked on areas such as private teaching, translation and interpreting. All of these activities have been the implementation of the SCL implementation in the entrepreneurship course.

However, all these positive activities above did not touch the heart and mind of all students equally and optimally. Only a small number of them were stimulated and motivated to start a business, most of them just stayed away. They were worried to start because they were afraid to be out of their comfort zones. They only wanted to involve themselves as donor or as assistant in the groups of entrepreneur. This was clearly seen during the team performance evaluation at the end of the entrepreneur activity. Students who were active and independent showed a dominant role indirectly in presenting the whole activities and result of group activities. Meanwhile, other students just took their name in the groups. They tended to be silent when they were asked for their opinion or just gave swirling answers. This indicated their weakness in understanding the application and concept of entrepreneurship. This condition happened repeatedly year by year in the entrepreneurship course.

The phenomenon above becomes the background of applying the Self-Directed Learning (SDL) in entrepreneurship course. LP3M UNAND in the SCL Implementation Guide [2] describes that Self-Directed Learning (SDL) is a learning model that the learning initiative comes from students and they are responsible for completing their learning, with or without the others' help. The classroom action research with the SDL learning model is tried out in Class-A of entrepreneurship course. This research aims to examine two problem formulations. They are (1) the augmentation of student's competence after the application of SDL in the entrepreneurship course

(2) the augmentation of student's motivation after the application of SDL in the entrepreneurship course. The classroom action research with the SDL learning model in the entrepreneurship course is expected to fill in the description of learning outcomes that have been formulated in the KKNI-based curriculum for undergraduate students.

The application of SDL in the entrepreneurship course is conducted after having the MoU of the PPMP No.:T.015/UN.16.18/PT.01.03 on April 1st, 2020. The implementation of the Classroom Action Research (CAR) is arranged after taking mid-semester examination and after the academic affair released the regulation of Work from Home (WfH) and Study from
Home ( $\mathrm{SfH}$ ) at Universitas Andalas. This policy is due to the outbreak of Covid-19 detected in early March 2020. This pandemic causes teaching and learning activities apply Work from Home (WfH) and Study from Home (SfH) to complete lectures in the even semester 2019/2020.

One way to break the chain of this pandemic is by implementing social distancing and physical distancing along with other medical procedures that must be obeyed. This pandemic causes all students to be sent back to their home. They can gather and look after each other with their family. The distance between students and campus certainly affects the teaching and learning activities. Remote teaching is done to maintain the running of remote class with various choices of teaching models and teleconference platforms. The availability of internet network is one of the challenges in doing remote class in this pandemic.

\section{METHODS}

\subsection{Probabilistic Automata}

In the current era of 4.0, education can be accessed from classes to cyberspace. Classroom learning activities are not sufficient anymore. Lecturers and students collaborate to share and support each other's functions. Therefore, we need a curriculum that can connect all components in teaching and learning activities to work together with a comprehensive understanding. The switch in class roles allows for Classroom Action Research (CAR) to try out new things in teaching and learning activities. In this connection, Subyantoro [3] formulated that Classroom Action Research (CAR) is a research that is systematically reflective toward the various actions taken by educators who are also as researchers from the formulation of a plan to the assessment of real actions in the classroom in the form of teaching and learning activities and to improve teaching and learning activities.

From this formulation, it can be concluded that Classroom Action Research (CAR) is done to improve the conditions in teaching and learning activities. Educators are asked to be sensitive and corrective about the phenomena in teaching and learning activities. The relationship between educators and students is one of the keys in establishing the smooth communication to obtain teaching and learning outcomes.

Many things affect teaching and learning activities. One of them is the technology acceleration which depends on the current needs. The growth of technology encourages independent person to increase the quality optimally. Educators are asked to be able and familiar in using technology in teaching and learning activities. The use of social media such as WhatsApp groups to communicate actively inside and outside teaching and learning activity, in order to share, correct, and discuss related materials or tasks, are needed. The use of channels as a medium of inspiration can also be obtained from YouTube, which displays various educational videos to support teaching materials. The availability of these technology products can be utilized maximally in 
increasing students' competence and motivation in teaching and learning activities.

The use of technology in teaching indicates that SCL has been carried out in classroom activities. The Classroom Action Research (CAR) in the entrepreneurship course tries the application of SelfDirected Learning (SDL). This is because of the group's performance is not as good as expected in previous semester. The occurrence of this phenomenon in teaching and learning activities has been described in the background. The trial of the application of SDL is expected to augment the competence and motivation of students in independent creativity in the entrepreneurship course.

In implementing SDL, students perform their assignments individually. Performing these independent tasks starts from collecting data, analyzing, and describing the results. Fellow students can work together during peer reviews and class discussions using the Padlet application. The use of the Padlet application in peer reviews is to elicit more focus and responsibly to their partners. The results of peer reviews and independent assignments become measurement for student's competence and motivation. Lecturer plays as an active role as supervisor, motivator, corrector and facilitator. This condition is expected to trigger the participation of all students in all assignments. All of these assignments dig more and more student's potencies. Tasks in a group can not trigger all participants to involve and reduce some participant's motivation to improve their capability.

The application of SDL in the midst of a sudden pandemic attack has made teaching and learning activities in the entrepreneurship course adapt to the student's current conditions which are far from campus and all learning facilities. This led students to apply the SDL by observing and analyzing any potential conditions in their hometown. Lecturers are required to be observant in any the opportunities and provide strong motivation to the students. Maintaining the students' mentality to be able to fight and find the gaps. The home atmosphere, family and financial situation must be considered carefully and thoroughly. The application of SDL in the entrepreneurship course in the midst of a pandemic make students more sensitive to the situation and conditions of their hometown. The realization can be seen in student's involvement in family business.

There were 8 teaching and learning activities in the entrepreneurship course meetings that have been held. Remote teaching uses academic portal., WhatsApp group application, Padlet, mail, and YouTube channel. These were chosen because not all regions have good internet network services. The application of SDL at the 8 meetings was elaborated with topics and assignments that adapted to the regional conditions of each student.

In the first meeting, students were given socialization and education about the importance of SDL implementation in the entrepreneurship course in the
Covid-19 pandemic. This meeting was also as the first meeting after the mid semester test. Lecturers and students shared stories about pandemic conditions in their respective areas. Lecturers encouraged students to look for entrepreneur gaps in their respective areas while obeying the procedures in breaking the Covid-19 chain. Because of it was not possible to continue the business plan that has been formulated in the classroom before the pandemic. The application of SDL got wider because students ought to know and explore any closest potentials in their hometown. What can I do in my hometown? This was the topic that students discussed in the second meeting later.

In the second meeting, we held a discussion entitled What can I do in My hometown? There were many exciting stories. Basically, family is the most beautiful and valuable thing in joy or sorrow. In this meeting, each student began to get an overview of their entrepreneur activities. My Chance is the next topic to be discussed. Before the next meeting, students formulated 2 possible plans that they would do. They uploaded this formula in their respective Padlet columns that would be evaluated by peer reviewer and lecturer.

In the third meeting, the class discussed the results of the evaluation of the possible formulation in the entrepreneur activities they would do. This discussion summed up all the possible ventures. The criteria for business plans were based on the needs of the closest community and the smallest use of capital. To finalize the business plan, they analyzed the positive and negative impacts of Covid-19 for Study from Home. These assignments would be collected before the next meeting.

In the fourth meeting, the discussion revolved around the results of the evaluation of condition and situation in their Study from Home. This discussion encouraged them to be honest in contributing later. Supervisors evaluated the psychological and financial conditions of students so that they could provide the right direction. As a comparison for business activities in other areas during the pandemic, students browsed related videos from YouTube. This task was reported for the next meeting.

In the fifth meeting, remote class discussed the business activities in other regions from some videos in YouTube channel. This information provided enlightenment for students that the Covid-19 pandemic is attacking all lines of life and we must be strong to fight and overcome it together. After analyzing and considering many things, students decided the business activities to do. Obtaining profit was certainly not the main aim in this business activities. The spirit of family and mutual cooperation is the strong foundation for the business activities in the entrepreneurship course. The formulation of the Simple Business Plan (SBP) was the next topic.

In the sixth meeting, students already had the SBP formula to be reported and evaluated together. Each 
student explained briefly and clearly about their chosen business activities. For more details, the SBP was evaluated by lecturer and peer reviewer. Class discussion was continued then.

In the seventh meeting, the results of the evaluation served as a guide for each student to revise the SBP as best as possible. SBP was applied after the seventh meeting and was evaluated together in the last meeting. Students practiced their business activities and reported the progress later.

In the eighth meeting, students shared stories about their business activities in the previous week. Students prepared the report of their business activities in videos uploaded $t$ o the YouTube channel. The video would be a final project for their final semester test. There were lots of exciting stories and they wanted to contribute in the completion of teaching and learning activities in the entrepreneurship course by applying the SDL. At the end of this meeting students filled out a questionnaire to measure their competence and motivation. The questionnaire was given as the parameter to measure the learning outcomes in the SDL method.

\section{RESULTS AND DISCUSSION}

The two problem formulations in this Classroom Action Research (CAR) are (1) how to increase student competence after the application of SDL to the KWU MK? how to increase student motivation after the application of SDL to the KWU Court? The trial of the application of SDL in the entrepreneurship course is expected to seek the description of learning outcomes that are formulated in the KKNI-based curriculum for undergraduate students. This Classroom Action Research (CAR) have output in (1) the draft of revised RPS (2) articles that will be presented at a national seminar.

This teaching and learning activities in the entrepreneurship course is applied after the mid test and ends on final test. All attendance lists, student assignments and lecturer's notes are collected for recapitulation. The returned questionnaires are recapitulated to be recorded. This article will be included in one of the national seminars that has been scheduled by LP3M UNAND.

Covid-19 causes some changes in various things. The implementation of SDL in teaching and learning activities in the entrepreneurship course has been changed. The plans for direct selling and open booths in the campus were eventually carried out independently by students from their respective regions. The replacement of SBP that has been presented at the UTS, adapts to the conditions and situations of each student's hometown. Students make new SBP by exploring their own potency and their environment to be used in their business activities. The limitations of movement, communication and people's purchasing power are important considerations in formulation their new SBP independently.

The application of SDL provides a variety of student learning experiences when distance learning is carried out. Adaptation of the learning environment from home, learning outcomes at RPS, limited mobility and availability of internet services are triggers for students to explore their creativity in learning. The SDL method gives students the flexibility to formulate concepts of business activities and their implementation. Students gave each other suggestions in peer review and class discussion. The lecturers are technical advisors for student's business activities. Every business activities is unique because it is created in different situation and condition for each student.

Evaluation through the results of students' business activities and questionnaires that has been distributed to students showed augmenting in student's competence and motivation after applying SDL in the in the entrepreneurship course. This improvement can be seen from the independence of students in studying, creating and implementing the concept of business activities in the Simple Business Plan (SBP) independently and responsibly until completion. The results of student's business activities are reported in the form of videos uploaded to the YouTube channel. The independence of student's business activities in SDL can be used as a comparison to student's group business in previous years. This shows that the application of SDL can increase student's competence and motivation in independent business activities. This competence and motivation are obtained from potencies and environmental supports in independent business activities. The implementation of independent student's business activities provides students to be entrepreneur as early as possible. SDL encourage students in maturing mindset and strengthen student relationship with their families and their environment.

SDL in distance learning of the entrepreneurship course is applied using several media. They are: 
a. UNAND Academic Portal

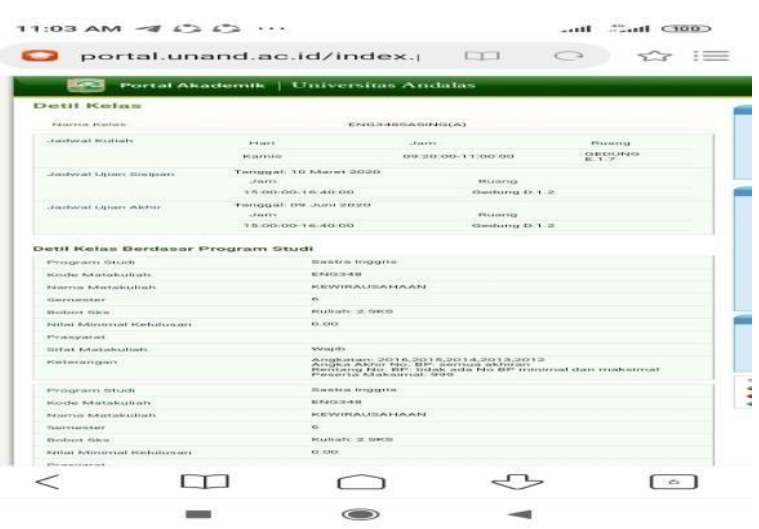

b. WhatsApp Group on https://chat.whatsapp.com/DD5U4w kCUWjJPiKv3nFQOP

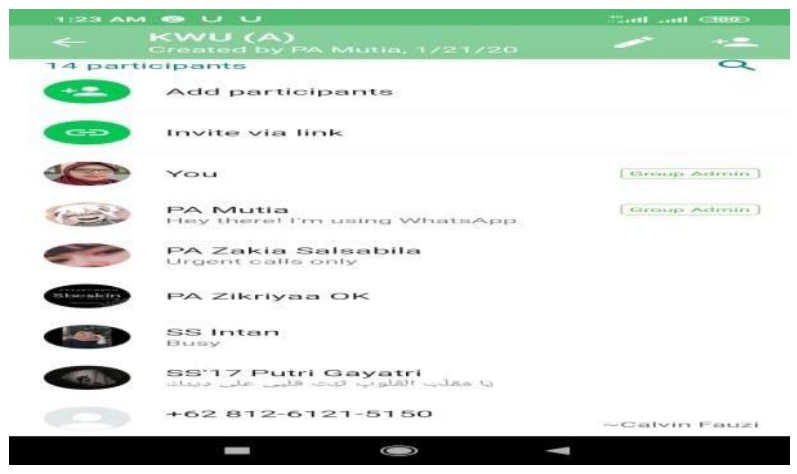

c Padlet application on https://padlet.com/dhiantasri sasing unand/uegfqgf4e923

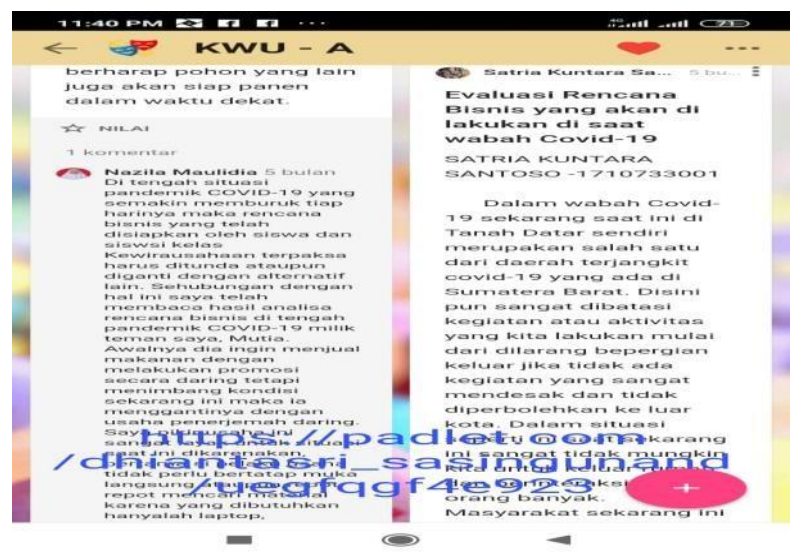

d E-mail

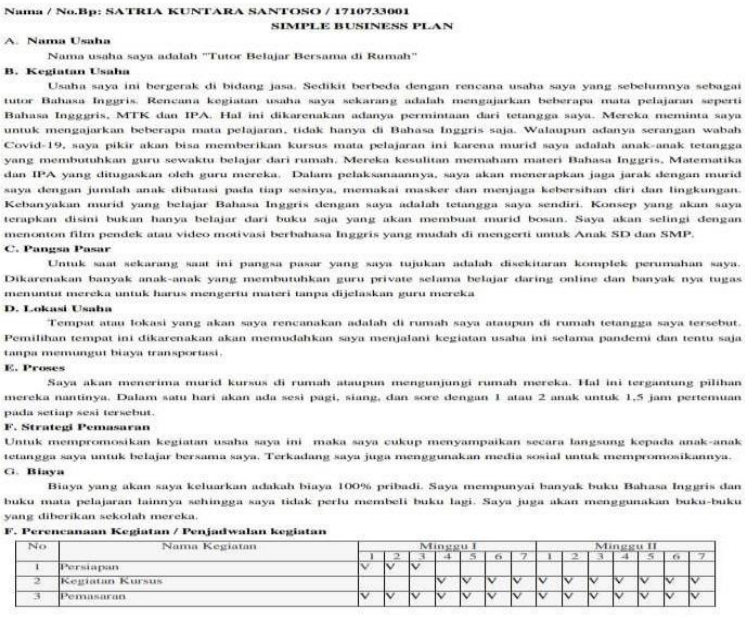

e. Youtube Channel

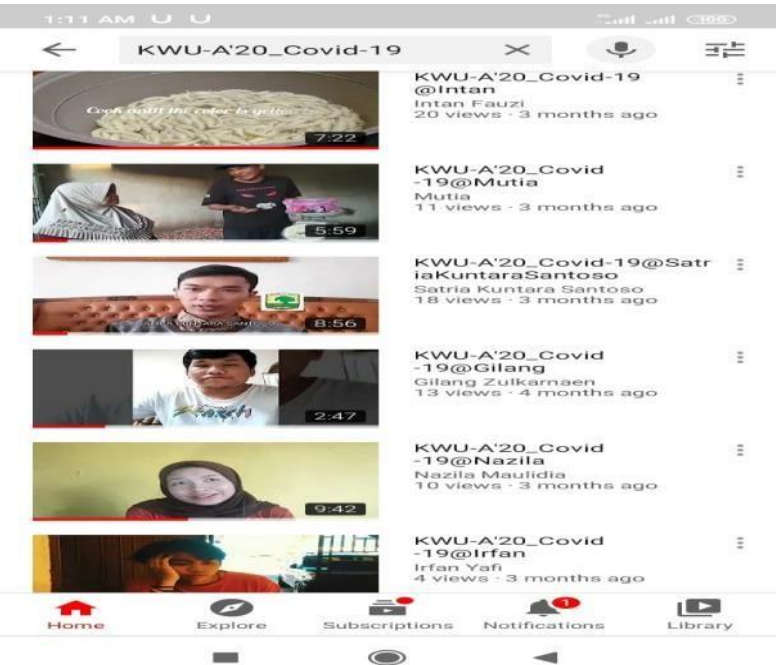

\section{CONCLUSION}

After graduating entrepreneurship course, students are expected to have understanding in the concept and application of Self-Directed Learning (SDL) in teaching and learning activities. Meanwhile, Covid-19 pandemic causes the regulation of Work from Home (WfH) and Study from Home (SfH) at Universitas Andalas. The implementation of SDL can be seen in student's competence and motivation in entrepreneurship. Students elaborate their own potency and their environment in doing independent entrepreneur activities. In this case, classroom action research shows the augmentation of student's competence and motivation in entrepreneurship can be elicited by applying SDL in entrepreneurship course. 


\section{ACKNOWLEDGMENT}

This work supported by LP3M UNIVERSITAS ANDALAS

\section{REFERENCES}

[1] Kasali, R.K. 2010. Modul Kewirausahaan untuk Program Strata 1. Jakarta: Rumah Perubahan

[2] LP3M UNAND. 2014. Panduan Praktis Pelaksanaan Student-Centered Learning (SCL): Meningkatkan Interaksi Mahasiswa dan Dosen dalam Pembelajaran. Padang: LP3M UNAND [3] Subyantoro. 2019.

Penelitian Tindakan Kelas:

Metode, Kaidah Penulisan, dan Publikasi. Depok: PT.

Raja Grafindo Perkasa 